
internationales

vol. $19-n^{\circ} 3 \mid 2003$

Moyen-Orient : mutations récentes d'un carrefour migratoire

\title{
Perspectives on labour migration in Israel
}

Sarah S. Willen

\section{(2) OpenEdition}

1 Journals

\section{Édition électronique}

URL : https://journals.openedition.org/remi/2691

DOI : 10.4000/remi.2691

ISSN : $1777-5418$

Éditeur

Université de Poitiers

\section{Édition imprimée}

Date de publication : 12 décembre 2003

Pagination : 243-262

ISBN : 2-911627-35-0

ISSN : 0765-0752

Référence électronique

Sarah S. Willen, «Perspectives on labour migration in Israel », Revue européenne des migrations

internationales [En ligne], vol. $19-n^{\circ} 3$ | 2003, mis en ligne le 09 juin 2006, consulté le 14 avril 2022.

URL : http://journals.openedition.org/remi/2691 ; DOI : https://doi.org/10.4000/remi.2691

Ce document a été généré automatiquement le 14 avril 2022.

(c) Université de Poitiers 


\title{
Perspectives on labour migration in Israel
}

\author{
Sarah S. Willen
}

The Setting: Tel Aviv's Central Bus Station, “capital of the foreign workers"1

1 Half a century after the establishment of the State of Israel, a stranger meandering through Tel Aviv's labyrinthian, seven-story Central Bus Station would be surprised to hear not just Hebrew, or even just Israel's recognized languages of Hebrew and Arabic, Russian and Amharic, but rather a global cacophony of languages: Tagalog and Romanian, Nigerian languages like Igbo and Yoruba, and Ghanaian languages like Twi and Fante. May be Mongolian. Certainly Spanish. Perhaps the South African click language, Xhosa ${ }^{2}$.

2 For residents of south Tel Aviv, the Central Bus Station - or Takhana Mérkazit, as it has come to be called in multiple tongues - is a commercial and social hub as much as a hub for intra- and inter-city transportation. It houses a grocery store, two full-service pharmacies, dozens of stores selling clothing and jewellery, housewares and hardware; an indoor market selling everything from superglue to men's undershirts and from pornographic videos to tall glass water pipes; a post office; branches of all major Israeli banks; and dozens of food stands and restaurants including a wildly popular McDonald's.

But it is not commercialism that has made Tel Aviv's Takhana Mérkazit, the largest of its kind in the Middle East, unique. Rather, the Central Bus Station - full of life, sound, music, color, opinions, negotiations, and consumer goods suiting a vast spectrum of taste and temperament - is also, always, full of people - many of whom are not Israeli. In local parlance, these people - Filipinos and Colombians, Romanians and Chinese, Nigerians and Thai - are collectively described as ovdim zarim, or "foreign workers".

4 While this varied and polyglot group is monolithically represented in Israeli public discourse by the single term "foreign workers", the cultural, linguistic and religious diversity the term conceals is clearly striking. More precisely, this striking diversity was visible until the implementation of a massive deportation operation declared by Israeli Prime Minister Ariel Sharon in 2002. The goal of the campaign, in the language 
of the Migration Police, was to deport 50,000 undocumented workers from the country by the end of 2003, later raised to 100,000 by the end of 2004 .

Introduction

But we are jumping ahead of ourselves. How did Israel become home to an astonishingly diverse population of approximately 240,000 migrant workers, constituting $10 \%$ of the labour force, by the year 2000 (Kemp and Raijman, 2003)? This rapid transformation over the course of the 1990s, despite its widespread economic, administrative, and social implications, took place quietly. Although these new migratory trends represent increased participation in the global economy and even, perhaps, another badge of entry into the family of industrialized nations, they also pose a fundamental challenge to Israel's "migration regime" (Freeman, 1992), defined as "the institutional and ideological principles that determine the set of goals, agencies, and procedures - including both formal legal provisions and informal institutionalized practices - employed by states to deal with migratory flows" (Rosenhek 1999: 578). Since its establishment, Jewish immigration, governed by a basic principle of "explicit and formal demarcation between Jews and non-Jews," has been the country's very raison d'être (Rosenhek 2000: 53). Despite the restrictiveness of Israel's migration ideology and policy, the phenomenon of labor migration emerged relatively quickly but without garnering substantial opposition or radically transforming the face of the country, at least in part because there is in Israel - at least for now - but one Takhana Merkazit and one South Tel Aviv.

6 In this context, the objectives of the present research note are fourfold. First, this discussion provides an overview of the phenomenon of transnational labour migration in Israel for a European readership. Second, it begins to explore the details and consequences of the dramatic policy shift embodied in the recent mass deportation campaign, which was reaching a peak as this research note was being composed. Third, it demonstrates how cultural anthropology, and in particular its hallmark mode of inquiry - ethnography - can broaden both the epistemological and the empirical scope of research on this topic. While several qualitative studies have been published to date (Kemp et al, 2000; Rosenhek and Cohen, 2000; Cohen, 1999; Von Breitenstein, 1999), very little (cf. Raijman et al, 2003) has relied on ethnographic tools or engaged the rich comparative literature on transnational labour migration (Ehrenreich and Hochschild, 2003; Hirsch 2003; Hondagneu-Sotelo 2001, 1994; Parreñas 2001; Anderson 2000; Constable 1997; Mahler 1995; Rouse 1995, 1992; Glick Schiller et al 1992). Ethnographic investigation based on long-term field research and active participation in migrants' individual and community lives is uniquely capable of bringing to the fore one of the most crucial yet least frequently heard voices in the current literature on transnational labour migration in Israel: the voices and stories of migrant workers themselves. Finegrained ethnographic research can also elucidate the broader discursive, ideological, and social contexts in which migration trajectories are constructed, negotiated, and experienced. In the space available, this research note begins to map out some of these actors and influences and to explore how institutional policies and practices affect the lives of individual migrants.

7 Fourth, while ethnographic research "from below" (Smith and Guarnizo, 1998) is important both in itself and for purposes of comparison, it can also illuminate how both migrants' lived experience and host state policies and practices are implicated in broader processes whereby currencies and commodities, people and ideas circulate 
transnationally. Far from being "deterritorialized" or "unbounded," such processes involve a diverse array of competing micro-, meso-, and macro-level factors (ibid.) and are anchored in geographic and social space both "by the policies and practices of territorially-based sending and receiving local and national state communities" and by the "grounded reality" of social relations and networks within and between home and host societies (Guarnizo and Smith 1998: 10).

Thus research on transnational labour migration should draw migrants' voices into larger conversations that explore these three levels of analysis and the dynamic interrelationships among them: first, the micro-level of migrants' experience, best approached through ethnographic field research; second, the meso-level of state and institutional policies and practices, well-studied in the Israeli context; and finally the macro-level of global political economic trends and processes. The vast and multidimensional task of unpacking these complex interrelationships, as Mahler (1998) points out, is inherently collaborative and interdisciplinary. Cultural anthropology has much to contribute to this endeavour.

To this end, the second half of the present research note begins to explore these issues through three brief ethnographic portraits of migrant families drawn from the findings of a 24 month ethnographic field study conducted in South Tel Aviv between 2000 and 2003. Research methods included participant observation in one NGO setting (the Open Clinic for Migrant Workers run by Physicians for Human Rights) and one municipal setting (the Mesila Aid and Information Center for the Migrant Community); structured and unstructured interviews with both "legal" and "illegal" migrants; participant observation in the home, family, and community lives of migrants from West Africa, the Philippines, and Eastern Europe; and participation in Israeli-organized as well as migrant-organized social, religious, and political events.

Recent scholarship

10 Scholars in a variety of fields have investigated multiple aspects of Israel's short and turbulent experience as a "host country." Issues addressed in the literature ${ }^{3}$ include the historical context of foreign labour recruitment to Israel (Bartram, 1998); patterns of labour market participation, community organization and claims-making (Kemp et al, 2000; Rosenhek and Cohen, 2000; Rosenhek, 1999; Lukumu, 1997); patterns of residence (Menahem, 2000; Schnell and Binyamini, 2000; Schnell, 1999); migrants' cultural backgrounds (Cohen, 1999; von Breitenstein, 1999); Israeli attitudes toward migrants (Raijman et al, 2003; Nathanson and Bar Tzuri, 1999; Rosenhek, in press); economic implications of labour migration for Israel and for migrants' home countries (Amir, 2002; Fefferman, 2000; Klinov, 1999); state and municipal policy dynamics (Kemp and Raijman, 2003, 2000; Alexander, 2001; Rosenhek, 2000, 1999); and labour migration trends as both symbolic and constitutive of Israel's changing cultural and national identity (Berthomière, 2001). Particularly in comparison to literature on other migration contexts, the absence of ethnographic research is a conspicuous lacuna.

The Migration policies of a "non-immigration state"4

11 The most comprehensive overviews of the phenomenon of labour migration in Israel have only been published in Hebrew thus far, (Kemp and Raijman, 2003, 2000; Rosenhek and Cohen, 2000), but articles in English by Rosenhek (2000; 1999), and Bartram (1998), provide a solid orientation for the English speaking reader. The discussion below presents a brief sketch of these fuller accounts while drawing attention to some of the 
more unique dimensions of Israel's encounter with this global phenomenon, particularly at the micro-level of individual lived experience.

Background context

A common refrain of Israeli politicians and bureaucrats is the paradoxical claim that "Israel is not an immigration country" (Rosenhek, 1999:580). This statement, as the juxtaposition of the present discussion and Berthomière's article in this volume clearly illustrates, is simultaneously true and false. Since Israeli citizenship is granted almost exclusively to individuals of Jewish descent ${ }^{5}$, it is virtually impossible for non-Jews from Moldova or the Philippines, Columbia or Ghana to become Israeli citizens. Nor do children born in Israel to non-Israeli parents receive any form of citizenship or residency rights ${ }^{6}$. How, then, did Israel find itself home at the beginning of the 2000 s to an estimated 250,000 non-Jewish, non-citizen, transnational migrant workers?

Israel's experience is in many ways similar to other labour-importing industrialized and globally competitive countries; the "pull" of increased demand for low wage unskilled laborers, through a range of formal and informal pathways, met the "push" of harsh Third World economic conditions. In Israel's case, widespread recruitment began after the first Intifada, when Palestinian construction and agricultural workers were unable to reach their jobs because of closures imposed on the West Bank and Gaza Strip by the Israeli army. In 1993, the government reluctantly approved the importation of a small number of migrant workers, ostensibly as a temporary solution to a temporary problem. Over time, dependence on foreign labour grew as the number of permits jumped from 4,200 in 1990 to 9,600 in 1993, and then tenfold to 103,000 in 1996 (Israeli Ministry of Labour and Social Welfare, cited in Bartram, 1998). At the same time, growing streams of undocumented migrants from a separate set of countries were arriving in Israel. Overall, the rapid and dramatic increase in the number of migrant workers between 1993 and 1996, both "legal" and "illegal," paralleled a marked decrease in the number of non-citizen Palestinians working in Israel (Israeli Central Bureau of Statistics, 2001, cited in Kemp and Raijman, 2003: 4). Whereas Palestinians constituted 4.5 percent of the Israeli labour force in 1993 (a drop from 6.5 percent the previous year) and migrant workers constituted $1.6 \%$, by 2000 Palestinians represented $3.3 \%$ of the labour force and migrant workers $8.7 \%$ (ibid: 8). By 2003, estimates placed the number of migrant workers between 10 (ibid: 1 ) and $12 \%^{7}$ of the labour force. At the same time, the Israeli economy was in a deep recession with unemployment at $10.6 \% t$ in November 2003 (Israeli Central Bureau of Statistics, 2003)

State-level policies and the paradox of legal status

Migrant workers in Israel are typically grouped into two legal categories: documented or "legal" workers who were recruited in their home countries to fulfill short-term contracts and then return home, and undocumented or "illegal" workers who reached Israel of their own accord via what can be described as the "tourist loophole" in Israel's rigid migration regime, a phenomenon I shall describe momentarily. "Legal" workers are concentrated in three sectors: agricultural workers from Thailand; construction workers from Romania, Bulgaria, and China (among other places); and caregivers for the elderly and disabled primarily from the Philippines. "Illegal" workers are employed in a variety of sectors but most prominently in domestic work such as housecleaning, childcare, and restaurant work (West Africans, South Americans, Eastern Europeans, and others). 

group: migrants who arrive as "legal" workers but subsequently lose their legal status. This third group of "formerly legal" workers has also been described as "illegal workers generated by the system" ("bilti hukiim totzeret ha'shita": Kemp and Raijman, 2003: 7). Upon arriving in Israel, "legal" workers are constrained by a government policy called the "bonding arrangement," or hesder ha'kvila. This arrangement, whereby work permits are issued directly to employers rather than to workers themselves, is designed to protect the interests of employers by granting them complete control over their employees for the entire duration of their employment - presumably identical with migrants' entire period of residence - in Israel. Instead of facilitating regulation and supervision, however, the "bonding arrangement" has yielded a wide range of problematic results, including the emergence of a large population of "formerly legal" workers who arrived with visas but stayed on after the voluntary or involuntary termination of their authorized work relationships (ibid: 13-15). As many as 53 percent of Israel's "illegal" workers are thought to have arrived in this manner (Bar Tzuri, 2000, cited in Kemp and Raijman, 2003: 14). The "bonding arrangement" has also generated serious human rights violations including numerous instances of exploitation and abuse described by Israeli NGOs as "trafficking in human beings" and employment under "slavery-like conditions" (Hotline for Migrant Workers, 2002) ${ }^{10}$. Space constraints preclude in-depth discussion of this important, and as yet gravely underinvestigated, topic.

In theory, Israel's central objectives regarding migrant workers have been 1) to limit the number of documented or "legal" workers entering the country; 2) to maintain minimal involvement in their living conditions; 3 ) to ensure such "legal" workers leave the country at the conclusion of their contracts thereby preventing their permanent settlement; 4) to prevent the entry of spontaneous undocumented or "illegal" workers; 5) to refuse "illegal" workers recognition as legitimate clients of the welfare state; and 6) to stimulate, either indirectly or directly - i.e., via arrest and deportation - their departure from the country (Rosenhek, 2000: 54-60). From the mid-1990s until summer 2002, however, these goals remained largely unfulfilled as successive governments, characterized by heterogeneity of principles and objectives from one agency to the next, maintained a position of "non-involvement" (ibid: 63), and deliberately refrained from developing consistent or long-term oriented policies. The resulting course of government action has been described as "chaotic" (Ma'ariv 15/9/03) and reflecting "asystematicity and irrationality" (Borowski and Yanay, 1997).

While the heterogeneity and asystematicity persist, the atmosphere on the ground changed dramatically with Prime Minister Sharon's 2002 declaration of a mass deportation campaign. The campaign, which is costing the Israeli state between US\$65-90 million ${ }^{11}$, hinges on what a growing body of critics identify as "a simplistic and deceptive parallel between two phenomena: 300,000 foreign workers, 300,000 unemployed"12 (Ha'aretz 23/9/03). Despite the faulty logic of its central claim (i.e., to instantly create jobs for Israeli workers) (Kemp and Raijman, 2003), and in the face of strong opposition from many journalists, scholars, NGO activists and others, this rhetorically powerful campaign has nonetheless received substantial state investment and, in a relatively short period of time, begun to radically transform the economic, social, and cultural phenomenon most visibly embodied in the Tel Aviv Central Bus Station. Moreover, the ultimate utility of mass deportation is thrown into question by

Revue européenne des migrations internationales, vol. $19-n^{\circ} 3$ | 2003 
the continued government approval for the importation of tens of thousands of additional workers (Ha'aretz 29/9/03).

The City of Tel Aviv-Jaffa and the state-municipal paradox

One of the most intriguing aspects of Israel's encounter with transnational migrant workers is the explicit contradiction between the policies and practices of the state, on one hand, and those of the municipality most deeply affected by their presence, the city of Tel Aviv-Jaffa, on the other. With 60-80,000 migrant workers constituting one-fourth of the city's overall population (Ha'aretz 10/6/03), the phenomenon is far from theoretical or abstract; as one municipal employee put it, "The state does not have a problem of foreign workers, we (local authorities) do" (cited in Kemp et al, 2000: 122). In 1999, with limited funds but lofty aims, the municipality established the Mesila Aid and Information Center for the Foreign Community, a social welfare organization that collaborates with other local and national agencies - and, to a lesser extent, with the highly politicized NGO community - to provide services, programs, and advocacy in areas such as children's health, education and wellbeing; community leadership development; and community crisis preparedness and intervention. Two principles govern Mesila's activities: first, a commitment to remaining uninvolved in debates about state-level policies such as deportation or, conversely, the possibility of granting residency status to migrants, and second, a commitment to helping migrants, as staff members reiterate time and again, "as long as they are here" (Mesila staff, personal communication). In the shadow of the government's explicit deportation-oriented agenda, Mesila continues to regard itself as a "warm, concerned, open home for the foreign community," ${ }^{13}$ thereby generating a peculiar situation in which "the state proceeds as if there were no migrants while the municipality acts as if there were no state" (Kemp and Raijman 2000; my translation).

Non-government organisations (NGOs)

Where Mesila takes pains to avoid confrontation with state-level authorities, the human rights oriented non-government organization (NGO) community does not. Organizations such as the Kav La'Oved Workers' Hotline, Physicians for Human Rights (PHR), the Association for Civil Rights in Israel (ACRI), and the Hotline for Migrant Workers in Prison use a range of legal, political, and media strategies to act in defense of migrants' codified rights and to advocate legislative and policy change. In addition to the profound roles these organizations have played in shaping both policy and public discourse, some also affect individual migrants' lives in more direct ways, either by providing legal counsel and advocacy (Kav LaOved, ACRI, the Hotline for Migrant Workers) or by providing medical services (the PHR Open Clinic).

Ethnographic research on the zones of interaction between these Israeli advocates and their migrant clients would provide fascinating insights into the constitutive role these organizations play - at times more constitutive than either the state or the municipality - in shaping individual experiences of labour migration in Israel. In particular, an ethnographic approach could illuminate the fascinating and often radical disjunctures between NGOs' principles and values, on one hand, and the way migrants experience those organizations' declarations, activities and programs on the other.

Why Israel?

21 In addition to "push" and "pull" factors in the Israeli economy and in migrants' home economies, a range of other sociological, cultural, and religious factors have also played 
a role in migrants' choice of Israel as migration destination. Three such reasons are discussed below.

The first reason, applicable particularly to "legal" Filipina caregivers who come to Israel after working elsewhere in the Filipino labor diaspora such as Singapore, Hong Kong, or Saudi Arabia, pertains to the possibility of improved work and living conditions. Some migrants like Marlene, ${ }^{14}$ an unmarried woman in her early 30s, decided to come to Israel after working for ten years as a maid for a middle-class family in Hong Kong. There she felt underappreciated, underpaid, and exploited. When she learned she could earn two to three times more in Israel for what she expected to be less strenuous work as an elder-care provider, she quickly seized the opportunity. Marlene and other Filipina migrant workers like her often describe their work conditions in other countries, particularly in East Asia and the Persian Gulf, as isolating, humiliating, and/or underpaid, and their stories resonate with the growing social scientific literature on Filipina labour migration (Parreñas, 2003, 2001; Anderson, 2003, 2000; Constable, 2003, 1997). Before migrating, this relatively small group of migrating women hoped and expected not only to earn more money, but also to find a more humane work environment, even if it would draw them into yet another new society and culture even further from home. Potential migrants tend to pay careful attention to the rumours and stories told by co-nationals who have worked abroad as they make their own migration decisions. Particularly for Filipina transnational migrants seeking work on a documented basis, Israel's reputation has made it more desirable than other possible destinations.

A second reason for choosing Israel is what I call the "tourist loophole," referring to the possibility of obtaining a tourist visa to enter the country and then stay on as an "illegal" worker. Given its profound archaeological, biblical, and spiritual significance, the "Holy Land" has attracted tourists and, in particular, religious pilgrims for centuries. In the modern Israeli state, the tourism industry has been a basic building block of the national economy, although it took a plunge following the outbreak of the second Intifada in October 2000. Throughout the 1990s, and despite the country's rigid "migration regime," Israel thus employed a liberal visa policy designed to encourage such tourism, both religious and secular. Thus thousands of migrants were able to obtain individual visas or join tour or pilgrimage groups in their home countries and, after a quick turn through religious and secular tourist destinations, make their way to the metropolitan Tel Aviv area seeking work cleaning houses and offices, in restaurants, or performing other blue collar, often physically demanding jobs. Throughout most of this period, opportunities were plentiful, and migrants were able to earn, remit, save, and often loan funds to finance the chain migration of friends or relatives who then joined them in Israel. This "loophole" thus facilitated the entry of tens of thousands of migrants from West Africa, South America, Eastern Europe and elsewhere who would have preferred migrating to more desirable destinations, particularly in North America or Western Europe, but could not.

A third distinctive reason for Israel's attractiveness as a migration destination is the appeal of being in the Holy Land. The vast majority of both "legal" and "illegal" migrant workers belong to some Christian denomination (Catholic, Evangelical, Russian Orthodox, Ethiopian Orthodox, etc.), and many explain they were deeply attracted to the idea of living for a time in the Holy Land and visiting the sites where Jesus lived. While it seems highly unlikely that Israel's distinctiveness as the "Holy Land" is the 
central or sole reason most migrants have come to Israel, the country's religious significance does, for many, deeply enhance its desirability. Once residing in Israel, migrant communities and individuals devote substantial time and energy to contemplating the religious and theological dimensions of their presence, particularly within the dozens of churches that have sprung up in South Tel Aviv. For the most part, the Israeli authorities have refused to acknowledge or engage theological discourses of belonging or membership (Paz 2003; Willen 2003a). Nonetheless, as one municipal official - the director of Mesila - has pointed out, "Whether we like it or not, this is the Holy Land to many different religions." 15

With this context in place, let us now look briefly at how this complex array of objective and subjective motives and constraints shapes the migration trajectories and the everyday lives of migrant workers in Israel.

Views from south tel aviv: structure, agency, and indeterminacy in the lives of migrant workers

The ethnographic portraits presented below were selected with two goals in mind. First, they convey a sense of the sheer variation, alluded to in the introduction, in migrants' countries of origin, levels of education, migration pathways, and family structures. Second, they begin to map out how different groups of migrants confront, negotiate, and experience the convoluted assortment of policies and practices, opportunities and constraints shaping labour migration in Israel. Together these ethnographic excerpts convey a sense of the complexities - economic and pragmatic; cultural and psychological - of migrants' everyday life worlds.

Four themes merit particular attention. First is the "paradox of legal status," whereby "illegal" migrants often enjoy better work and living circumstances, and greater personal autonomy than "legal" workers. A second key theme is the way state, municipal and NGO actors disseminate a complicated and contradictory assortment of messages which effectively confuse high-stakes actors, the Israeli public, and migrants themselves. The "state-municipal paradox," whereby the municipality of Tel Aviv-Jaffa provides social services to migrants while the state invests actively in deportation, is one manifestation of this cacophony of messages. Another is the outward similarity at least from migrants' perspectives - between municipally provided services, particularly in the area of health, and services provided by private partisan organizations like the NGO Physicians for Human Rights. Migrants who utilize available services tend not to differentiate among the various migrant-friendly agencies and organizations. As such, the often sharp ideological distinctions among municipal, NGO, and sometimes even state attitudes tend to dissipate in the realm of practice.

A third theme is the substantial variation in the way different groups of migrants, including groups sharing the same legal (or lack of legal) status, occupy vastly different positions within the Israeli "ethnoscape" (Appadurai, 1996) and, as such, experience labor migration in Israel in substantially different ways. Finally, the excerpts highlight the overarching sense of indeterminacy which overshadows individual migrants' everyday lives. Let us now turn to the ethnographic portraits themselves.

Ethnographic portrait \#1: Marina and Raymond

Marina, from the northern Philippines region of Pangasanan, and Raymond, from the central Philippines island of Cebu, both came to Israel in the mid-1990s to work "legally" as live-in elder-care providers. Marina had no care-giving experience before coming to Israel although she had worked as a uniformed maid and housekeeper in 
Singapore. Raymond, on the other hand, worked as a nursing aide in a Filipino hospital before coming to Israel and, like countless other migrant workers in Israel and across the globe, paradoxically left his family behind in order to support them and ensure their well-being (Constable, 1997; Parreñas, 2002; Ehrenreich and Hochschild, 2003; Raijman et al, 2003). At the end of her contract in Singapore, Marina jumped at an opportunity to migrate to Israel for several of the reasons mentioned earlier: she felt constricted and humiliated living under the thumb of an unfriendly, demanding employer, she heard she could earn considerably more money in Israel, and as a Christian she was eager to exchange Singapore for an opportunity to live in the "Holy Land." Both Marina and Raymond were legally employed for several years after their arrival. They met in a Tel Aviv suburb where each was caring for an two elderly Israeli, and over time, a romance bloomed. Gradually their relationship strengthened, and after a time Marina unexpectedly became pregnant.

Like many other Filipino caregivers in Israel, Marina's pregnancy eventually led to her loss of legal status due to the stipulations of the "bonding arrangement." As the pregnancy progressed, it became too difficult for Marina to perform the physical aspects of caring for her employer, an elderly diabetic woman whom she affectionately called Ima, Hebrew for "mother." She resigned several months before giving birth to their daughter, Jennielyn, and with her resignation and the termination of her employment contract, she permanently lost her legally defined right to live and work in Israel.

31 As Marina explained to me in the winter of 2002 while we watched Jennielyn play, living in Israel without a visa is difficult and perpetually anxiety-producing; one never knows when the police might be waiting around the corner. On the other hand, she and many others are keenly aware that "being illegal" entails - or until the mass deportation campaign in 2002 entailed - certain advantages, primarily in terms of freedom from the constricting "bonding arrangement." Until then, many "formerly legal" migrants actually preferred to work without visas since it enabled them to live wherever they chose rather than where their employer dictated; they had much greater control over their use of time, particularly evenings and weekends; they had greater control over their work schedule (although work is not always reliable); and they could negotiate for higher wages or leave an unsatisfactory job for a more lucrative, more convenient, or otherwise more suitable opportunity (Kemp and Raijman, 2003: 14; Rosenhek, 1999).

As an "illegal" worker, Marina believes she is at less risk of arrest than many other "foreigners" as she described herself and others, for several reasons. First, men are perceived as being - and at the time of our conversation were - at greater risk of random arrest on the street than were women. Second, Marina feels that as a Filipina her risk was lower than that of "foreigners," particularly African migrants. Although she no longer has a visa herself, many other Filipinas (including many of her friends) do. While virtually no West Africans work in Israel "legally," the fact that 19,000 Filipinos do so in the year $2000^{16}$ has made a substantial difference in Marina's and in other Filipinos' subjective sense of safety from the risk of arrest.

Despite these potentially mitigating factors, Marina travels around the city with her small daughter whenever possible. "Why do you carry Jennielyn with you everywhere?" I asked her early in our acquaintance. Marina is barely five feet tall, and her growing toddler, moody and prone to temper tantrums like others her age, is a 
heavy burden, especially following a day of shopping at Shuk HaCarmel, the open-air market in the center of town. Her answer was quick and unequivocal: "She [pointing to Jennielyn] is my visa!" Marina, like many other migrants in Tel Aviv, is well aware of the police's reluctance to arrest parents, especially mothers, of small children. Picture Marina, struggling to climb onto a crowded bus on a Friday afternoon dragging several heavy bags of rice, vegetables, fish - plus a crying, pigtailed, two year old "visa," desperately in need of a nap. Marina once joked to me, parroting the American credit card commercial, "Visa - don't leave home without it!"

While no official law or policy prevents the Migration Police from arresting parents, this cautionary measure constitutes one of the few ways migrants could control their subjective sense, if not their objective risk, of arrest. During the late 1990s and early 2000s, some women like Marina made efforts to foreground their informal immunity by carrying their children around with them whenever possible. Others felt comfortable carrying their children's birth certificates, ${ }^{17}$ printed in Hebrew and issued by Israeli hospitals, as evidence of their parenthood and, consequently, as a badge of immunity. I often saw adults grab children by the hand to make an evening trip to the corner store or "borrow" other people's children for an afternoon of errands in order to minimize their change of "getting caught." By mid-2003, however, when the operation to deport 100,000 migrant workers - including families - was in full force, Filipinos and other migrants with whom I spoke felt this strategy was no longer reliable.

As Marina explained to me, even after losing her legal status her nationality and outward appearance allowed her a freedom of movement other migrant groups

- particularly West Africans - never enjoyed in Israel. Still another migrant group is even better equipped to "pass" as legal than Filipinos: migrant workers from the Former Soviet Union (FSU). Unlike undocumented West Africans, who cannot "blend" into any other group, or undocumented Filipinos, who are to an extent buffered by the presence of so many "legal" Filipinos, Russian-speaking migrants from the FSU can often blend inconspicuously into the vast sea of authorized olim khadashim, or "new immigrants," from the same countries and sometimes even the same cities, towns or neighborhoods in Russia or Ukraine, Azerbaijan or Belarus. Tanya and Sergei, to whom we now turn, are two such individuals.

Ethnographic portrait \#2: Tanya and Sergei

Sergei, originally from Baku, Azerbaijan, and Tanya, from the large city of Zaparozhye in southern Ukraine, live in a cramped, one-room rooftop apartment in a bustling south Tel Aviv neighbourhood just across the highway overpass from the Central Bus Station. Both in their late 30s and nominally Russian Orthodox, the couple has been married 14 years. They met in the Ukrainian city of Odessa, where Tanya was completing a 5-year chemistry degree at the university and Sergei was on leave from his work as a seaman on a transoceanic shipping vessel. Several years after they were married, the Soviet Union collapsed and the Ukrainian economy took a severe beating. Reluctantly, the couple decided Sergei would follow the lead of a neighbor and travel to Israel with a tourist visa in search of work.

Upon arriving, Sergei found a job with relative ease through the large Russian-speaking community. Several years later Tanya, taking a similar route, left her aging mother, sister, and beloved niece to join her husband. As an "illegal" resident and worker, employment in her profession - chemistry - was out of the question, but she had little difficulty finding work cleaning offices and homes. A highly verbal and expressive 
person, Tanya felt paralyzed and humiliated by her lack of Hebrew language skills. Since Filipinos and most West Africans, like many Israelis, speak passable if not fluent English, they can largely get by without knowing Hebrew. Migrants from the FSU - few of whom have studied English - are in a different position; while they can manage within Russian speaking social and commercial circles, native-born Israeli employers and shopkeepers, bus drivers and neighbours typically know no Russian. Through careful listening and bold requests for assistance and instruction from employers and acquaintances, Tanya slowly began to pick up the language and, within two years, was linguistically fluent albeit thoroughly analphabetic

Tanya also became familiar enough with Jewish holidays, customs, and religious practices to "pass" as an olah khadasha, or welcomed and ratified new immigrant, in Israeli social settings. Unlike members of other migrant groups, Russian-speakers can "pass" as Israeli - even without tucking crosses inside their shirts - because so many of the Russian olim khadashim are themselves not Jewish; their entitlement to citizenship is derived from Jewish kinship ties through either genealogy or marriage. Many of those who do identify as Jewish possess only minimal familiarity with Jewish traditions and practices. Hence the ease with which Tanya can discuss Jewish customs and holidays often preempts questions about her formal legal and religious identity.

But cultural and linguistic development were not Tanya's only goals during her first years in Tel Aviv. She and her husband also took advantage of their reunification to return to an earlier, failed project: trying to have a child. Despite the anticipated costs and difficulties, Tanya's lack of medical insurance, and the knowledge a child would interfere with their ability to earn and save, Tanya in particular was resolute. After six miscarriages over their first eleven years of marriage, some of which she attributes to chemical exposure during her studies and work in Ukraine, their wish finally came true in January 2001 when Tanya delivered a healthy baby girl, Larissa, at a public hospital in Tel Aviv.

Larissa is now $21 / 2$, and she and her parents often socialize with Sonya, a neighbor of Tanya's from Zaparozhye, and her husband and two young daughters. Like Tanya, Sonya is not Jewish. Yet she married and started a family with a Jewish man, moved to Israel, learned Hebrew, obtained professional recertification, and now works as a nurse at the public hospital where Tanya's daughter was born. The family recently purchased a comfortable apartment just outside of Tel Aviv. Once neighbours in Ukraine and now neighbours once again in Tel Aviv, Tanya and Sonya - both university-educated women in their mid-30s - are divided by a legal abyss. Sonya can work in her profession, take out a mortgage, receive subsidized health care and otherwise enjoy the benefits of Israeli citizenship, whereas Tanya, who has neither home phone nor mailing address, cannot. While the fact of legal status may be clear-cut in the eyes of (at least some) Israeli authorities, these categorizations - particularly with respect to Russian migrants and immigrants - mask a complicated social reality.

West African migrant workers in Tel Aviv come to Israel via similar routes and for similar reasons, yet their migration experiences are quite different from those of migrants from either the Philippines or the Former Soviet Union. Let us now turn to Janie and William, a mixed Nigerian-Ghanaian couple whose experience brings some of these similarities and differences to light.

Ethnographic portrait \#3: Janie and William 

physical fights. The death of William's father, which translated into costly funeral expenses for the ceremony in Ghana and which William felt compelled to fund but could not attend, further aggravated the situation. In addition to ongoing conjugal stress and increasing anxieties about money, the growing fibroids began causing Janie such severe pain that she could no longer complete a full day's work, and she occasionally found herself immobilized for hours - sometimes in public places like bus stops or post offices - until the pain would subside. She made monthly visits to the doctor in East Jerusalem for checkups, but nothing he prescribed alleviated the pain. During her second trimester, the doctor recommended an advanced sonogram and advised her to visit the sole medical facility in Tel Aviv fully accessible to migrant workers: the low-tech, volunteer-run Open Clinic run by the NGO Physicians for Human Rights (PHR).

When Janie came to the clinic, she was convinced that her doctor had referred her out of fear that harm had come to the foetus. The clinic's gynecologist on duty tried to reassure her that the sonogram was routine. Since the clinic has reached informal price-reduction agreements for some basic diagnostic tests and procedures with area public hospitals, the clinic staff was able to schedule a sonogram for her. The clinic staff also provided three other pieces of information. First, Janie was referred to a local Israeli doctor in Tel Aviv - a clinic volunteer - who provides reduced-cost prenatal care. Second, she received a Hebrew flyer for her employers explaining how they can register migrant employees for National Insurance delivery benefits. ${ }^{18}$ Third, she was 
advised to register the infant at her neighborhood's Tipat Chalav child development center once he was born.

In addition to providing Janie with useful information and access to locally available, affordable medical services, the visit also linked her into a web of services which were available to her but of which she had been almost entirely unaware. While she might have stumbled upon some of these opportunities on her own, her encounter with the Open Clinic substantially increased her sense of control over and responsibility for the pregnancy.

Yet she did not notice or consider the fact that each of these services was provided by a different kind of organization and was accessible to her for a different reason. Whereas the Open Clinic was created expressly to serve the health needs of migrant workers and, in particular, "illegal" migrant workers, the sonogram was available because of an informal agreement between this private, politically oriented NGO and a state-funded public hospital. The reduced-cost prenatal care visits were offered by an especially dedicated physician who, unlike many of his colleagues at PHR who volunteered once a month at the Open Clinic, opened his doors exclusively to migrant patients for a full four hours each week. Finally, visits to the municipally run Tipat Chalav child development center were eventually available to her son through an entirely different arrangement; following municipal policy, the neighbourhood clinics are open to and equally subsidized for all residents of Tel Aviv regardless of citizenship or legal status. Despite the vast differences among these institutions' attitudes toward and level of willingness to accept migrant patients, it is important to note that Janie experienced the rest of her prenatal and eventually her son's initial development care as a more or less seamless package. Moments like this one, in which mixed messages conveyed by meso-level institutions are reinterpreted by migrants at the micro-level, offer a unique lens onto transnational migration processes and the social and ideological issues they generate. Fine-grained ethnography is an especially useful strategy for peering through such lenses.

One and a half years after the birth of their son, Janie became pregnant for a second time, again much to William's dismay. Again, the tensions increased, as did the number of arguments and the financial anxieties. The escalating deportation campaign only increased stress levels within the family. Then in June 2003, when Janie was six months pregnant with their second child, William was arrested at 7:00 a.m. at a bus stop just outside their flat and shoved into a white police van. Luckily for them, a Nigerian neighbour witnessed the arrest and immediately reported back to Janie, who sped to the police station in a taxi. After pleading with the police officers to release her husband and begging them to have mercy on her and their $11 / 2$ year old son and unborn child - and despite a bitter argument between the two of them the previous evening - Janie succeeded in obtaining her husband's temporary release. While the couple feels their days in Israel are now numbered, William is not prepared to return to Ghana empty-handed for fear of the shame and humiliation he would endure. Nor is he willing to start a new life in Janie's community in Nigeria, where he does not speak the language and would know no one but his wife. When I spoke with them in August 2003, the couple was contemplating moving to Uganda.

Conclusion

49 As this research note has demonstrated, the Israeli encounter with transnational labor migration has been structured by, and has generated, a complicated and contradictory 
array of laws, policies, and practices. To date, important studies have investigated this complex set of circumstances and its historical, sociological and economic implications, some with considerable sophistication and nuance. Yet such studies have tended to analyze labor migration in relation to the declared values and goals of the Israeli state and Israeli society to the distinct neglect of one crucial set of voices: those of migrants themselves. A central feature of the present discussion, therefore, is its urgent call for greater attention to migrants' experiences at both the individual and the community levels.

50 While the intrinsic importance of listening to migrants cannot and should not be underestimated, considerably more is at stake in calling for this analytical shift. As Smith and Guarnizo contend in their edited volume Transnationalism From Below (1998), simply giving voice to the micro-level perspectives of migrants is by no means sufficient. Instead, research on transnational labor migration should draw migrants' voices into larger discussions of all three levels of analysis and the dynamic interactions and interconnections among them: first, the micro-level of migrants' experience, best approached through ethnographic field research; second, the mesolevel of state and institutional policies and practices, well-studied in the Israeli context; and finally the macro-level of global political economic trends and processes. As Mahler (1998) has pointed out, such a vast and multidimensional research task is inherently collaborative and interdisciplinary, and the time is ripe for anthropologists to join sociologists, political scientists, and other scholars in shaping the conversation about transnational labor migration in Israel, both in itself and in comparative context.

51 These two analytical shifts - first, to greater emphasis on ethnographically grounded, migrant-centered analyses and second, to a multi-level, interdisciplinary research orientation - generate a multiplicity of potential avenues for future research in the Israeli context. In concluding, I would like to propose several particularly fruitful directions for further investigation.

52 - Transnational labour migration to the "Holy Land". How has Israel's status as the "Holy Land" framed migrants' initial desires to migrate to Israel, their everyday interactions with Israelis, and the ways in which they understand, negotiate, and/or contest their living and working conditions at the periphery of Israeli society? How have these perspectives affected migrants' efforts at claims-making vis à vis municipal and state authorities, if at all?

53 - Comparative configurations of legal status. How are "legal," "illegal," and "formerly legal" migration statuses configured in Israel? How do these configurations compare to those operating in other host countries (De Genova, 2002), and how do they shape migrants' everyday lives (Willen, 2003a, 2003b, 2003c)?

54 - Migration conditions, rights discourses, and transnational dialogue among migrants. Many migrants in Israel interact with migrants in other host countries, and some have lived and worked elsewhere themselves. How does knowledge of other migration contexts influence migrants' expectations and experiences of Israel? How do Israeli authorities and individuals respond to comparisons drawn on the basis of such knowledge and interaction?

55 - Israeli citizens' perspectives on transnational labor migration. In addition to the missing voices of migrants, the voices of Israeli citizens are also largely absent from current scholarship on transnational labour migration in Israel. ${ }^{19}$ How do Israelis 
regard these migration trends and their potential short- and long-term impacts on the Israeli state and Israeli society?

As the ethnographic excerpts included here begin to illustrate, a substantially different picture of transnational labour migration in Israel emerges when analytical attention is shifted from the perspective of state, municipal, and civil society actors to the perspectives of migrants themselves. In this respect, cultural anthropological methods and concepts can provide a crucial counterbalance to current research strategies. Only by integrating micro-, meso-, and macro-levels of analysis, however, can we fully understand Israel's encounter with transnational labour migration either in itself or in comparison to other instances of this increasingly pressing global phenomenon.

\section{BIBLIOGRAPHIE}

ALEXANDER Michael (2001) Comparing Local Policies Toward Migrants: A Proposed Analytical Framework and Preliminary Survey Results. Metropolis Conference, Rotterdam, the Netherlands, www.international.Metropolis.net.

AMIR Shmuel (2002) Overseas Foreign Workers in Israel: Policy Aims and Labor Market Outcomes, International Migration Review, vol.36 (1): pp.41-57.

ANDERSON Bridget (2000) Doing the dirty work? The global politics of domestic labour, New York: Zed Books.

ANDERSON Bridget (2003) Just Another Job? The Commodification of Domestic Labor in Barbara Ehrenreich and Arlie Russell Hochschild (eds.), Global Woman, New York: Metropolitan Books.

APPADURAI Arjun (1996) Modernity at large: Cultural dimensions of globalization, Minneapolis, Minn.: University of Minnesota Press

BAR-TZURI Roni (2000) Foreign Workers Deported from Israel 1995-1999, Jerusalem: Ministry of Labor and Social Welfare, Manpower Planning Authority.

BARTRAM David V. (1998) Foreign Workers in Israel: History and Theory, International Migration Review, vol.32 (2): pp.303-325.

BASSOK Moti (2003) In 2003, for the first time in 14 years, the number of foreign workers will decrease. Ha'aretz 29/9/03 [Hebrew].

BERTHOMIERE William (2001) The Immigration of Foreign Workers: A Mirror of Israel's Changing Identity in Paul Kennedy and Catherine J. Danks (eds.), Globalization and National Identities: Crisis or Opportunity?, Hampshire, England: Palgrave, pp.161-174.

BOROWSKI Allan and YANAI Uri (1997) Temporary and Illegal Labour Migration: The Israeli Experience, International Migration, vol.35 (4): pp.495-509.

COHEN Erik (1999) Thai Workers in Israeli Agricultural in Roby Nathanson and Lea Achdut (eds.), The New Workers: Wage Earners from Foreign Countries in Israel, Tel Aviv: Hakibbutz Hameuchad [Hebrew]. 
CONSTABLE Nicole (1997) Maid to Order: Filipina Domestic Helpers in Hong Kong, Ithaca: Cornell University Press

CONSTABLE Nicole (2003) Filipina Workers in Hong Kong Homes: Household Rules and Relations in Barbara Ehrenreich and Arlie Russell Hochschild (eds.), Global Woman, New York: Metropolitan Books.

DE GENOVA Nicholas (2002) Migrant "Illegality" and Deportability in Everyday Life, Annual Review of Anthropology, vol.31: pp.419-447.

EHRENREICH Barbara and HOCHSCHILD Arlie Russell (ed.) (2003) Global Woman: Nannies, Maids, and Sex Workers in the New Economy. New York: Metropolitan Books.

FEFFERMAN Binyamin (2000) Foreign Workers Employed Illegally in Israel in Dilek Çinar et al (ed.^eds.), Irregular Migration: Dynamics, Impact, Policy Options, Vienna: European Centre.

FREEMAN Gary (1992) "The consequence of immigration policies for immigration status: A British and French comparison" in Anthony Messina et al (eds.), Ethnic and Racial Minorities in Advanced Industrial Democracies, New York: Greenwood Press.

GLICK SCHILLER Nina, BASCH Linda and SZANTON BLANC Christina (1992) Transnationalism: A New Analytic Framework for Understanding Migration in Nina Glick Schiller et al (eds.), Towards a Transnational Perspective on Migration, New York: New York Academy of Sciences.

GUARNIZO Luis E. and SMITH Michael P. (1998) The Locations of Transnationalism in Michael P. Smith and Luis E. Guarnizo (ed.), Transnationalism from below: Comparative urban and community research, New Brunswick, NJ: Transaction.

HIRSCH Jennifer S. (2003) A courtship after marriage: Sexuality and love in Mexican transnational families, Berkeley: University of California Press

HONDAGNEU-SOTELO Pierrette (1994) Gendered transitions: Mexican experiences of immigration, Berkeley, Calif.: University of California Press

HONDAGNEU-SOTELO Pierrette (2001) Doméstica: Immigrant Workers Cleaning and Caring in the Shadows of Affluence, Berkeley: University of California Press

HOTLINE FOR MIGRANT WORKERS (2002) "For You Were Strangers": Trafficking in Human Beings and Modern Slavery in Israel [Hebrew].

ISRAELI CENTRAL BUREAU OF STATISTICS (2003) Main Indicators.

ISRAELI MINISTRY OF LABOR AND SOCIAL WELFARE (2001) Report of the Committee to Assess the Scope of Foreigners' Participation in the Israeli Economy [Hebrew].

ITIM NEWS SERVICE (2003) Foreign workers make up 1/4 of Tel Aviv's population. Ha'aretz - English edition, $10 / 6 / 03$.

KEMP Adriana, RAIJMAN Rebecca, RESNIK Julia and SCHAMMAH GESSER Silvina (2000) Contesting the limits of political participation: Latinos and black African migrant workers in Israel, Ethnic and Racial Studies, vol.23 (1): pp.94-119.

KEMP Adriana and RAIJMAN Rebecca (2000) Foreigners" in the Jewish State: The New Politics of Labor Migration to Israel, Sotziologia Yisraelit [Hebrew], vol.3 (1): pp.79-110.

KEMP Adriana and RAIJMAN Rebecca (2003) Foreign Workers, Israel: Adva Center, Report No13.

KLINOV Ruth (1999) The contribution of labor migration to the economic growth of workers' countries of origin in Roby Nathanson and Lea Achdut (eds.), Wage Earners from Foreign Countries in Israel, Tel Aviv: HaKibbutz HaMeuchad [Hebrew]. 
LUKUMU Matabisi (1997) Migrant Workers in Israel: With Insights on Black Africans. Public Policy, Tel Aviv: Tel Aviv University.

MAHLER Sarah J. (1995) American dreaming: Immigrant life on the margins, Princeton, N.J.: Princeton University Press.

MAHLER Sarah (1998) Theoretical and Empirical Contributions Toward a Research Agenda for Transnationalism in Michael P. Smith and Luis E. Guarnizo (eds.), Transnationalism from below: Comparative urban and community research, New Brunswick, NJ: Transaction Books.

MENACHEM Gila (2000) Jews, Arabs, Russians and Foreigners in an Israeli City: Ethnic Divisions and the Restructuring Economy of Tel Aviv, 1983-1996, International Journal of Urban and Regional Research, vol. 24 (3): pp.636-654.

NATHANSON Roby and BAR-TZURI Roni (1999) Survey of Public Opinions Towards Workers from Foreign Countries in Roby Nathanson and Lea Achdut (eds.), The New Workers: Wage Earners from Foreign Countries in Israel, Tel Aviv: HaKibbutz HaMeuchad [Hebrew].

PARRENAS Rhacel Salazar (2001) Servants of globalization: Women, migration, and domestic work, Stanford, CA: Stanford University Press

PARRENAS Rhacel Salazar (2003) The care crisis in the Philippines: Children and transnational families in the new global economy in Barbara Ehrenreich and Arlie Russell Hochschild (eds.), Global Woman: Nannies, Maids and Sex Workers in the New Economy, New York: Metropolitan Books.

PAZ Alejandro (2003) Narrating themselves into the Nation: Latin American Undocumented Immigrants and Israel's Transformist Hegemony, American Anthropological Association Annual Meetings, Chicago, Illinois.

RAIJMAN Rebeca, SEMYONOV Moshe and SCHMIDT Peter (2003) Do foreigners deserve rights? Determinants of public views towards foreigners in Germany and Israel, European Sociological Review, vol.19 (4): pp.379-392.

RAIJMAN Rebeca, SCHAMMAH-GESSER Silvina and KEMP Adriana (2003) International migration, domestic work, and care work: Undocumented Latina Migrants in Israel, Gender and Society, vol.17 (5): pp.727-749.

ROSENHEK Zeev (1999) The Politics of Claims-Making by Labour Migrants in Israel, Journal of Ethnic and Migration Studies, vol.25 (4): pp.575-595.

ROSENHEK Zeev and COHEN Erik (2000) Inclusion Patterns of "Foreign Workers" and the Israeli Migration Regime: A Comparative Analysis, Sotziologia Yisraelit [Hebrew], vol.Gimel (1): pp.53-77.

ROSENHEK Zeev (2000) Migration Regimes, Intra-State Conflicts, and the Politics of Exclusion and Inclusion: Migrant Workers in the Israeli Welfare State, Social Problems, vol.47 (1): pp.49-67.

ROSENHEK Zeev (in press) Migrant Workers in Israel: A Case of Non-occurrence of Anti-immigrant Political Mobilization.

ROUSE Roger (1992) Making Sense of Settlement: Class Transformation, Cultural Struggle, and Transnationalism among Mexican Migrants in the United States in Nina Glick Schiller et al (eds.), Towards a Transnational Perspective on Migration: Race, Class, Ethnicity, and Nationalism Reconsidered, New York: New York Academy of Sciences.

ROUSE Roger (1995) Questions of Identity: Personhood and collectivity in transnational migration to the United States, Critique of Anthropology, vol.15 (4): pp.351-380.

SCHNELL Itzhak (1999) Foreign Workers in South Tel Aviv-Yafo, Tel Aviv: Florsheimer Institute for Public Research [Hebrew] 
SCHNELL Itzhak and BINYAMINI Yoav (2000) Patterns of Social-Geographic Isolation Among Migrant Workers in Tel Aviv, Sotziologia Yisraelit [Hebrew], vol.Gimel (1): pp.111-132.

SHELEG Bambi (2003) Stop the Manhunt [L'hafsik et tzayd ha'adam], Ma'ariv 15/9/03 [Hebrew].

SINAI Ruth (2003) Foreigners pay the price, Ha'aretz - English edition, 23/9/03.

SINAI Ruth (2003) A first birthday for the Immigration Police, Haaretz - English edition, 31/8/03.

SMITH Michael Peter and GUARNIZO Luis E. (eds.) (1998) Transnationalism from below: Comparative urban and community research. New Brunswick, NJ: Transaction.

UNITED STATES STATE DEPARTMENT (2002) Country Report on Human Rights Practices: Israel and the Occupied Territories.

VON BREITENSTEIN Tina (1999) Filipino Workers in Israel in Roby Nathanson and Lea Achdut (eds.), The New Workers: Wage Earners from Foreign Countries in Israel, Tel Aviv: Hakibbutz Hameuchad [Hebrew].

WILLEN Sarah S. (2003) "Flesh of our flesh?": Configurations and Experiences of "Illegality" among Undocumented Migrant Community Leaders in Tel Aviv. American Anthropological Association Annual Meetings, Chicago, Illinois.

WILLEN Sarah S. (2003) Toward a Critical Phenomenology of "Illegality": Undocumentedness as Limitation and Resource for West Africans in Tel Aviv". International Association of Cross-Cultural Psychology Biannual Conference, Budapest, Hungary.

WILLEN Sarah S. (2003) "Flesh of our flesh?": Terror and Mourning at the Boundaries of the Body Politic Israeli Anthropological Association Annual Meetings, Neve Ilan, Israel.

\section{NOTES}

1. -Ayoob Kara, Chair of the "Special Parliamentary Committee on the Problem of Foreign Workers" at a joint session with the "Immigration and Absorption Committee" in recognition of International Migrants' Day, 18 December 2001.

2. -This article is part of a doctoral study on labor migration in Israel supported by grants from Fulbright-Hays, the National Science Foundation (Grant No. 0135425), the Social Science Research Council, the Wenner Gren Foundation, and the Lady Davis Trust at the Hebrew University of Jerusalem. Any opinions, findings, conclusions or recommendations expressed in this material are those of the author(s) and do not necessarily reflect the views of the funding agencies. The author is grateful to Zeev Rosenhek, William Berthomière, Carol Kleiner Willen, Mati Milstein, and Diana Smay for their helpful comments and suggestions on earlier drafts.

3. -In addition to the qualitative studies cited above.

4. -Kemp and Raijman 2000: 81.

5. -While naturalization procedures do exist, the Ministry of Interior is skeptical of and frequently rejects requests submitted according to these procedures.

6. -In January 2004, the Interior Minister established a commission to investigate the possibility of garanting some form of residence status to some (but not all) children of migrant workers (Ha'aretz 6/1/04).

7. -Kobi Hever, Deputy Director of the Budgets Division of the Ministry of Finance, cited in Ha'aretz 29/9/03. 
8. -Israeli Central Bureau of Statistics 2003. http://www.cbs.gov.il/indicators/ inden.htm. Accessed 5 November 2003.

9. -See Kemp and Raijman (2003) for distribution by labor sector and nationality. 10. -In its 2002 Country Report on Human Rights Practices, the United States State Department noted that Israeli "civil rights groups charged that unscrupulous employers often took advantage of illegal workers' lack of status to hold them in conditions amounting to involuntary servitude" (http://www.state.gov/g/drl/rls/ hrrpt/2002/18278.htm).

11. -One estimate places the figure between $300-400$ million New Israeli Shekels (NIS), or roughly US $\$ 65-90$ million (Ma'ariv 15/9/03). Another calculates the cost as 6,700 NIS, or roughly US $\$ 1,500$, per deportee (Ha'aretz 31/8/03).

12. -Kemp and Raijman (2003:18) cite figures of 237,000 unemployed Israelis and 250,000 migrant workers.

13. -Head of Social Services for the Municipality of Tel Aviv-Jaffa at a memorial service, held on 14 January 2003 at Mesila, for migrant workers killed in a suicide bombing that took place on 5 January 2003, in South Tel Aviv.

14. -All names used are pseudonyms.

15. -Director of Mesila, Lecture at an orientation seminar for Migration Police officers, Ramleh, 17 September 2002.

16. -In 2000 , for example, 19,000 Filipinos were "legally" employed in Israel (Israeli Ministry of Labour and Social welfare) 2001, Report of the Committee for Assessing the Scope of Foreigners' Participation in the Israeli Economy, cited in Kemp and Raijman, 2003: 10.

17. -Although Israel provides no form of legal status - nor even official birth certificates - to children like Jennielyn, many migrant workers presume -that Israel relies on North American or Western European-style model of citizenship whereby citizenship is granted on the basis of jus soli. These parents often express frustration and anger at Israel's refusal to grant their children any form of formal recognition. 18. -The National Insurance Institute covers the delivery expenses of migrant women for whom National Insurance taxes had been paid (Kemp and Raijman, 2003). During the late 1990 s and early 2000s, the arrangement applied to "illegal" as well "legal" workers, but more recently the Institute has made efforts to stop covering the expenses of "illegal" workers.

19. -While several opinion polls have been conducted to date, (Nathanson and BarTzuri, 1999; Raijman et al, 2003) no studies have explored the perspectives of Israeli citizens using qualitative research methods.

\section{AUTEUR}

\section{SARAH S. WILLEN}

Department of Anthropology, Emory University, Atlanta, Georgia - USA 